attributable to teething and which are due to associated conditions at the teething age when feeding changes are in progress. Sore buttocks, for example, may occur at this time, and it is almost impossible to say whether this can be "justly ascribed" to teething or not.

\section{The Vegetable Marrow}

Q.-My wife and I have independently noticed that our nights have been disturbed after eating vegetable marrow for supper. Is marrow known to contain a diuretic principle?

A.-While there is no reference to the vegetable marrow, Cucurbita ovifera, as containing a diuretic principle, other members of the Cucurbitaceae are said to contain one. The white gourd melon and the bottle gourd are diuretic according to K. M. Nadkarni's Indian Materia Medica (Bombay, 1927), and the United States Dispensatory (1943) says that bottle gourd is a native remedy for dropsy in the Sandwich Islands.

\section{Vesical Calculus}

Q.-A male patient has recurrent attacks of backache, sometimes radiating to the legs. $X$-ray shows a stone, the size of a lentil, at the neck of the bladder. Is surgical removal of the stone advised?

A.- It appears probable that the pain is due to the calculus impacted at the vesical neck. There should be no difficulty about removing it by perurethral methods through a cystourethroscope ; it can either be withdrawn or pushed back into the bladder and crushed. These are surgical measures,.' of course, but it is unlikely that without some such treatment the stone can be got rid of, although there is always a chance of spontaneous expulsion. It certainly should not be left where it is, otherwise a whole host of troubles, such as chronic prostatitis, which may be very serious, are likely to result.

\section{Dangers of Detergents}

Q. - (a) Have modern detergents any tendency to produce dermatitis of the hands? (b) Are they harmful to the bacterial flora of a domestic septic tank? (c) Do they help prevent the soakaway pit of a domestic sewage disposal system from "greasing up"?

A.- (a) Most modern detergents even when used in the strength recommended by the makers are alkaline, though less so than soaps and household powders. They are therefore capable of producing a traumatic dermatitis as a result of damage to the natural fatty and keratin protection of the skin surface. This may be avoided by the subsequent use of emollients. Dermatitis from specific sensitization may arise, but is rare.

(b) The use of detergents has created new problems in sewage purification. Research on this subject is at present going on in various parts of the country, but the results are as yet inconclusive. This is to some extent because detergents vary quite widely in their composition, and conclusions which are valid for one do not necessarily apply to the others. The results so far obtained by experiment would seem to show that detergents are not deleterious to a sewage purification plant in the quantities at present used, and it is probable that this conclusion applies also to domestic septic tanks.

(c) The tendency of detergents will be to prevent the greasing up of the soakaway pit, but we doubt if the quantities normally used will in practice make any appreciable difference.

\section{"Gammexane"}

Q.-What are the symptoms and signs of "gammexane" poisoning? Is it possible that effects noticed after the use of crude commercial powder, which contains impurities with a markedly unpleasant smell, are due to these impurities?

A.-Gammexane is the trade name for a preparation containing as its main ingredient the gamma isomer of hexachlorcyclo-hexane, sometimes called benzene hexachloride.

There are no reports of accidental poisoning in man, so that the symptoms to be described are those found in experimental animals. Cameron and Burgess (unpublished) describe the following symptoms in guinea-pigs and rabbits after a single poisonous dose given by mouth: "Increased respiration, restlessness, increased micturition, intermittent spasms, salivation, grinding of the teeth, backward movements, loss of balance, head retraction, and convulsions (at first intermittent and then sustained with limbs outstretched), ending in collapse and death. In large single doses the gamma. isomer causes death from functional disturbance of the central nervous system, especially of the respiratory centre, and this often results in cardiac failure and lung oedema." In chronic poisoning the animals exhibit constant muscular tremors culminating in convulsions of increasing severity until death. The fur of white rats often becomes markedly discoloured. There are no striking pathological changes in chronically poisoned animals.

The question mentions " effects" (presumably on man), but does not state their nature. The impurities in the commercial preparations are responsible for the smell and also for the unpleasant taint given to food by some preparations of hexachlor-cyclo-hexane. In experimental animals the symptoms produced by feeding commercial preparations or a mixture of the pure isomers are similar, so that there is no reason for supposing that these impurities have any special toxic properties.

\section{NOTES AND COMMENTS}

Thrombophlebitis Migrans.-Dr. JoHN GibBens (London) writes: As a postscript to your answer to the question on thrombophlebitis migrans in "Any Questions ?" (October 14, p. 901), I think your questioner ought to be told that this disease is often associated with carcinoma. I have personally seen three such cases, the first two associated with carcinoma of the stomach, the third with carcinoma of the head of the pancreas. The first case was unsuspected during life, and it was only. when a second case also proved to have carcinoma of the stomach that I made a search through the literature, to find that there are plenty of cases reported with this curious association. With the third case I guessed that the patient had carcinoma, but $x$ rays of the stomach showed nothing, though there could be no doubt about the malignant cachexia. The carcinoma was discovered post mortem. After this experience I should certainly be in favour of a thorough investigation for latent carcinoma.

\section{Corrections}

In the item of "Medical News" entitled "Visitor to Copenhagen" (October 21, p. 956) we stated that the anaesthesiology centre in Copenhagen has until now been in charge of anaesthetists from the U.S.A. This was incorrect, for in fact Dr. T. C. Gray, of Liverpool, is at the centre now, and will remain in Copenhagen for two months.

Dr. C. C. Ungley (Newcastle-upon-Tyne) writes: Your excellent leading article (October 21, p. 933) on the absorption of vitamin $B_{1,}$ is incorrect in one particular. It is true that Ternberg and Eakin (J. Amer. chem. Soc., 1949, 71, 3858) showed that a constituent of rormal gastric juice combines with vitamin $\mathbf{B}_{12}$ to render it microbiologically unavailable, and that Cuthbertson and I have confirmed this. On the other hand, we have not assumed-neither did Ternberg and Eakin - that the vitamin $\mathbf{B}_{12}$-combining factor was identical with Castle's intrinsic factor. Indeed there is already some evidence to the contrary (Prusoff, Amer. Chem. Soc., 1950, 118th meeting). I entirely agree that caution is needed in interpreting complex therapeutic experiments. I have already mentioned some of the difficulties involved in judging the absorption of vitamin $B_{12}$ from the oraldose/parenteral-dose ratio. An additional difficulty is the variable excretion of vitamin $B_{12}$ in the urine, which is likely to be greater after parenteral than after oral administration.

All communications with regard to editorial business should be addressed to THE EDITOR, BRITISH MEDICAL JOURNAL, B.M.A. HOUSE, TAVISTOCK SOUAR, LONDON, W.C.1. TELEPHONE: EUSTON 2111 TEURARS: A tiolog, Westcent, London. ORIGINAL ARTICLES AND LETTERS forwarded for publication are understood to be offered to the British Medical Journal alone.

Authors desiring REPRINTS should communicate with the Publishing Manager. B.M.A. House, Tavistock Square, W.C.1, on receipt of proofs.

ADVERTISEMENTS should be addressed to the Advertisement Manager, B.M.A. House, Tavistock Square, London, W.C.1 (hours 9 a.m. to 5 p.m.).

MEMBERS' SUBSCRIPTIONS should be sent to the SECRETARY of the

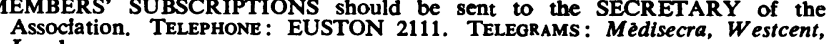
London.

B.M.A. Scotrish OFfice: 7, Drumsheugh Gardens, Edinburgh. 